\title{
Women in the University: The Fourth Phase
}

\section{by Margaret Gillett}

Following is the text of the 7th annual $F$. R. Scott Lecture, part of the Friends of the Library 1994-95 programme, delivered on Wednesday, 5 April, 1995, in Redpath Hall, McGill University.

Le texte de la $7^{e}$ conférence annuelle F.R. Scott qui fait partie du programme des Amis de la bibliothèque $1994-95$ est reproduit ci-dessous. La conférence a été donnée le mercredi 5 avril 1995, dans la salle Redpath de l'Université McGill.

$\mathbf{I}$ want to thank the Friends of the Library for having invited me to give the lecture named for one of McGill's most famous professors, a man of courage as well as intellect, a man whom we now all admire--though in his own day he had many opponents, even at McGill. We take this occasion to celebrate his multiple contributions to Canadian life: his poetry, his teaching, and his championing of civil liberties, especially his fight against Maurice Duplessis' infamous Padlock Law of 1937 and his advocacy of freedom of expression in the case of the ban on Lady Chatterley's Lover. We also remember him for his humanity and his wit. I know there are people here who still recall the note he left on the door of his McGill office when he went to court in that case. It read, "Gone to bat for Lady Chatt." I would like to have had Frank Scott on my side today as I "go to bat" for one of my favorite topics, "Women in the University."

As we all know, universities are extraordinarily complex institutions. No two are identical. All have different histories, all are the products of their culture and their time, but there are some general things we can say about them. As I have thought about the history of the university as an institution, I have identified four distinct, albeit overlapping, phases as far as women are concerned.

\section{PHASE I}

Quite simply, the universities of Phase I were characterized by the exclusion of women. They grew out of the monastic tradition and were essentially elite institutions with male students and teachers, patriarchal values, hierarchical structures and curricula strongly influenced by the writings of the church fathers, Aristotle and neo-Platonism. Phase $I$ was long and slow, dating roughly from the late 11 th century to the early 19th. It spans the time from when informal congregations of students (universitas) clustered around noted scholars became institutionalized as universities, from this formalization down to the development of separate, secular, post-secondary institutions for women.

The ancient foundations were based on an ideological dichotomy where male and female were opposites: man was strong, powerful, intelligent; woman was weak, dependant, emotional. From this view, higher learning would fit men into appropriate public or leadership positions but was unnecessary for women. Nature and experience would suffice for them in their supportive, domestic and child-bearing roles. These ideas may sound like very familiar clichés, but it is important to realize how they seeped into the very stones of the universities and could not easily or quickly be eradicated.

The general acceptance of male intellectual dominance obscured even the possibility that there could actually be intelligent women of scholarly bent. Yet intelligent women certainly did exist and some of them could find spiritual satisfaction, refuge from forced marriages and access to learning in the nunneries. Throughout the ages there have also been some few exceptional women who attained fame for their intellect. One was Trotula, who was said to have held a chair in medicine at Salerno in the 11th century, another was the redoubtable Hildegard of Bingen (10981179). In the 12th century, Hildegard founded a Benedictine abbey, wrote treatises on medicine and theology, composed poetry and music (which we still 


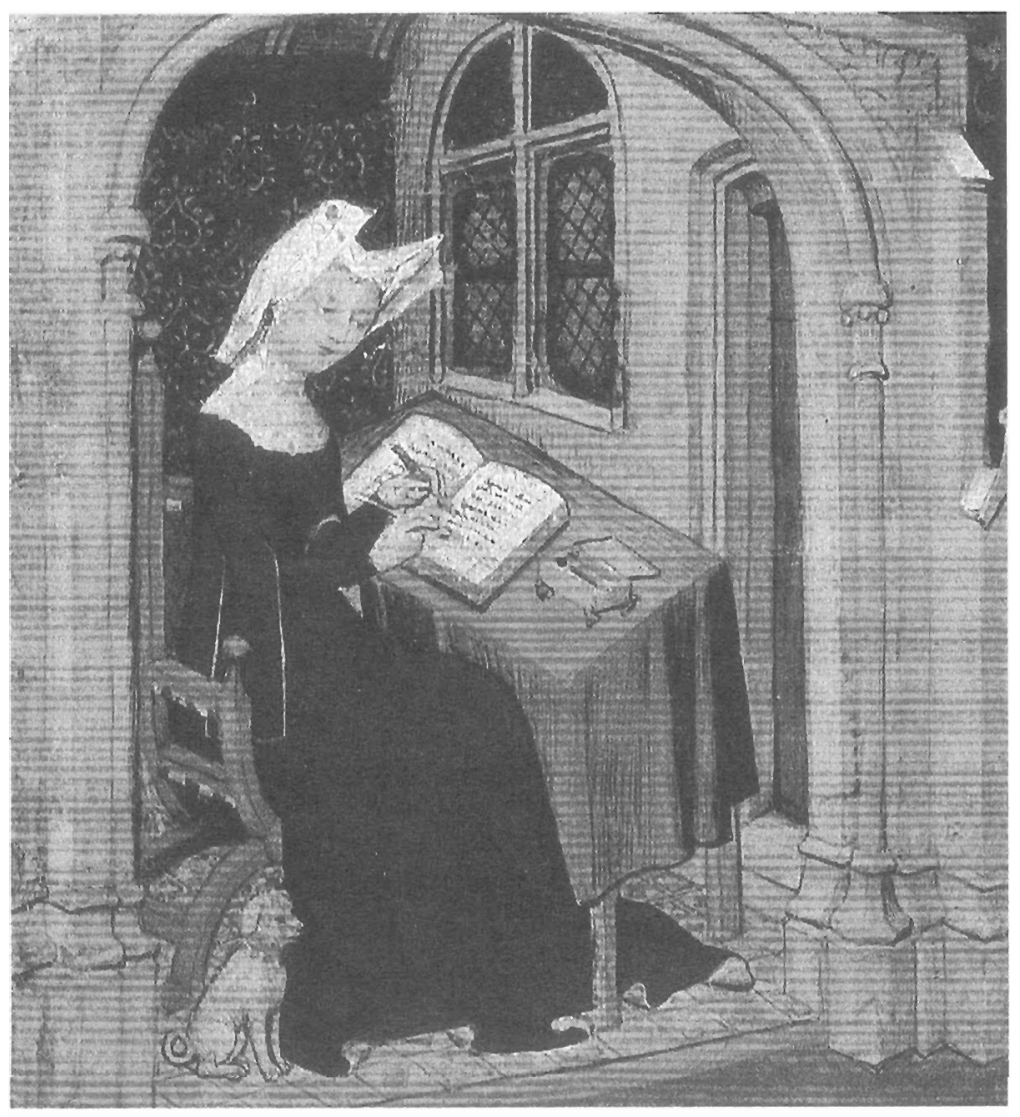

Figure 1. Christine de Pizan at her desk. (Reproduced by courtesy of the British Library Board)

hear today), and commanded respect from princes and prelates. There have also been intelligent women who protested their exclusion from the world of learning. At the beginning of the 15 th century, Christine de Pizan (Fig. 1) (1365-c. 1429) wrote in her remarkable work, The Treasure of the City of Ladies (1405):

If it were the custom to send daughters to schools like sons and to teach them the sciences properly, they would learn as thoroughly and understand the subtleties of all the arts and sciences as well as the sons.'

But for centuries, it was not the usual custom to send girls to school and women remained locked out of the academy. So Phase I, the purely patriarchal and masculine era of the university, lasted almost 800 years. That was a very long time indeed, a time in which traditions became entrenched and very difficult to change.

\section{PHASE II}

The second phase of the life of the university began in the 19th century and was the product of fundamental intellectual and social upheavals. The old hierarchies which had been undermined by the ideas of the Enlightenment and the American and French Revolutions, were further weakened by the forces of science, industrialization and urbanization. The university itself began to change. Largely through American influence, it became more secular, more broadly based with a wider clientele and a more practical curriculum. Through German influence, the academy became more concerned with research and graduate level teaching. Phase II was a period when, in the wider sphere, demands were being made for social reforms such as the abolition of slavery, property rights for married women and the female franchise. In this context, there was at last a chance for the women who had protested their exclusion to be taken more seriously. A nascent belief that women might be 
entrusted with higher learning was reinforced by the argument that the welfare of future generations depended on educated mothers.

Of course, there were countervailing ideas--some of them spread by "scientific experts" of various kinds-that the education of women would be both individually detrimental and socially harmful. For example, Dr. Edward Clarke of Harvard in his book Sex in Education or A Fair Chance for the Girls (1873), drawing on an idea from classical physics that the amount of energy is finite, argued that because women's delicate bodies had only a fixed amount of energy, rigorous studying would divert that energy toward the brain and away from the essential female reproductive organs. Higher education for women would thus result in madness, or the birth of deformed offspring, or produce a generation of barren women leading, ultimately, to the demise of the race.

For men of Dr. Clarke's persuasion, the idea of women in the university was an abomination. Yet the growing clamour for female education was partly satisfied by the appearance of separate colleges for women. Some of these "female academies, " seminaries and finishing schools had what were thought to be appropriately "ladylike curricula" offering literature, music, deportment and the like; others (Vassar, for example) considered themselves "real" colleges with rigorous, intellectual fare emulating the men's colleges. Both kinds of colleges flourished, especially in the United States, and they, along with normal schools for the training of elementary teachers, also gave opportunities for the employment of educated women. It might be noted, though, that the presidents of these institutions were quite often men--even if the Lady Principal did all the work.

It was just a matter of time before co-education in colleges was introduced. It is common to date the trend from about 1837 when women were first admitted to Oberlin, then a small residential college in the U.S. Midwest. However, this was not quite as enlightened as it might seem. It was not so much an idealistic acknowledgement of women's intellectual worth as unvarnished expediency. The trustees realized that the extra fees women would bring would help defray operating costs, and the women themselves would help with the domestic chores that male students could not be expected to perform.
In the well-established institutions for men, hostility and skepticism still greeted the idea of higher education for women and "the gentle sex" was kept at bay by one excuse or another--down to the lack of toilet facilities. Among those given in the 1870 s by McGill's Principal Dawson was not that women were not good enough for McGill, but that McGill was not good enough for them! $!^{2}$

Yet those few exceptional women who had appeared throughout the ages still existed and their voices were now being heard. In Montreal, courageous, intelligent, and ambitious young women like Grace Ritchie (Fig. 2), Rosalie McLea and Nellie Reid who won top marks in the matriculation examinations wanted access to McGill. Their mothers and other women supported them, encouraging them to approach the formidable Principal Dawson. Their cause was also supported by broadminded men in high places--some idealistic, some generous--who used their power to change the rules that excluded women. Lord Strathcona's offer to Principal Dawson of $\$ 50,000$ for the higher education of women was what made the crucial difference at McGill. ${ }^{3}$

This second phase was one where women were gradually and rather grudgingly allowed to enter the traditional male sanctum. It lasted for about 150 years and has not entirely played itself out. It was notable for its "firsts"--the first women to be admitted to established universities, the first woman to get a bachelor's degree (the first one in Canada was Grace Annie Lockhart, B.Sc. Mount Allison, 1875), the first M.A., the first Ph.D., the first M.D., the first professor, the first dean, the first Chancellor... the first to give the Frank Scott lecture! (And coming soon to a university near you, the first Vice-Principal).

McGill has the distinction of appointing the first woman full Professor in Canada. In 1912, Carrie Derick (Fig. 3) became Professor of Morphological Botany, but there were certain reservations that take some of the gloss off that story. Her promotion, which involved no salary increase but included the expectation that she should set up her male colleague's demonstrations, was really only a consolation prize and this was made excruciatingly clear to her. ${ }^{4}$

That was typical of Phase II, which was a period of peculiar ambivalence, characterized by "cat and mouse" 
Women in the University: The Fourth Phase

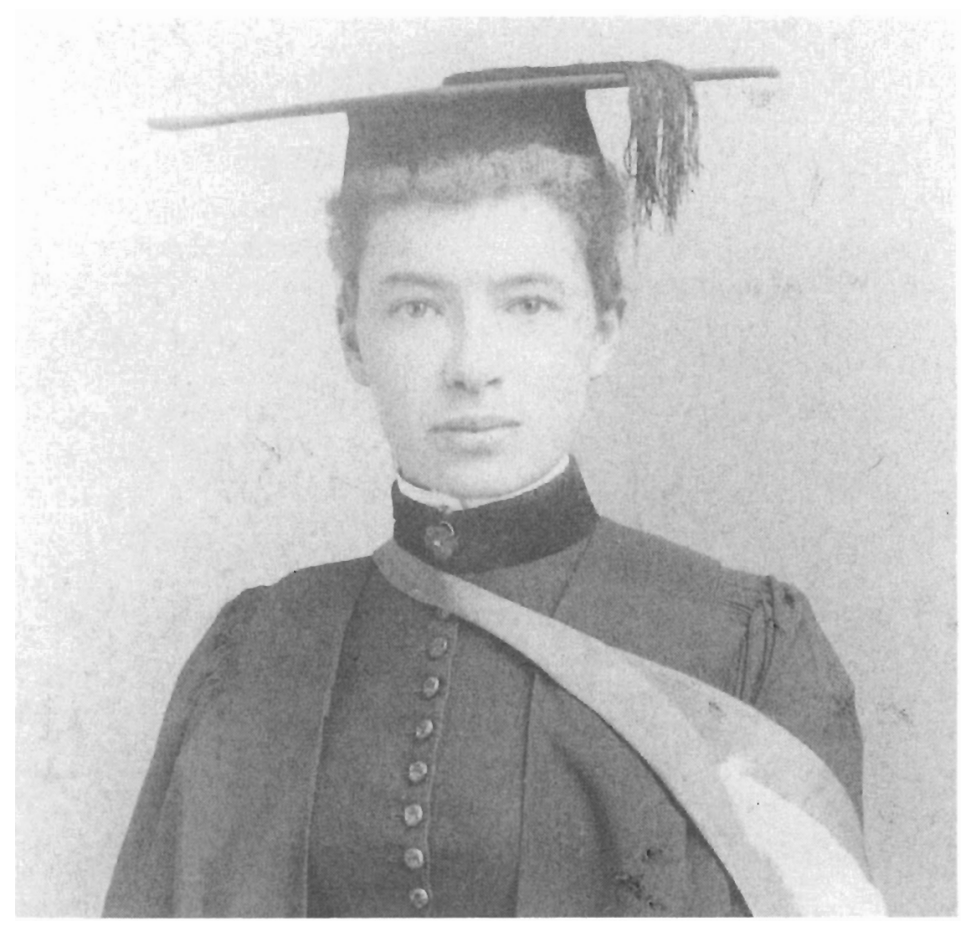

Figure 2. Grace Ritchie; valedictorian of the first class of women, 1888. (Photo: Notman)

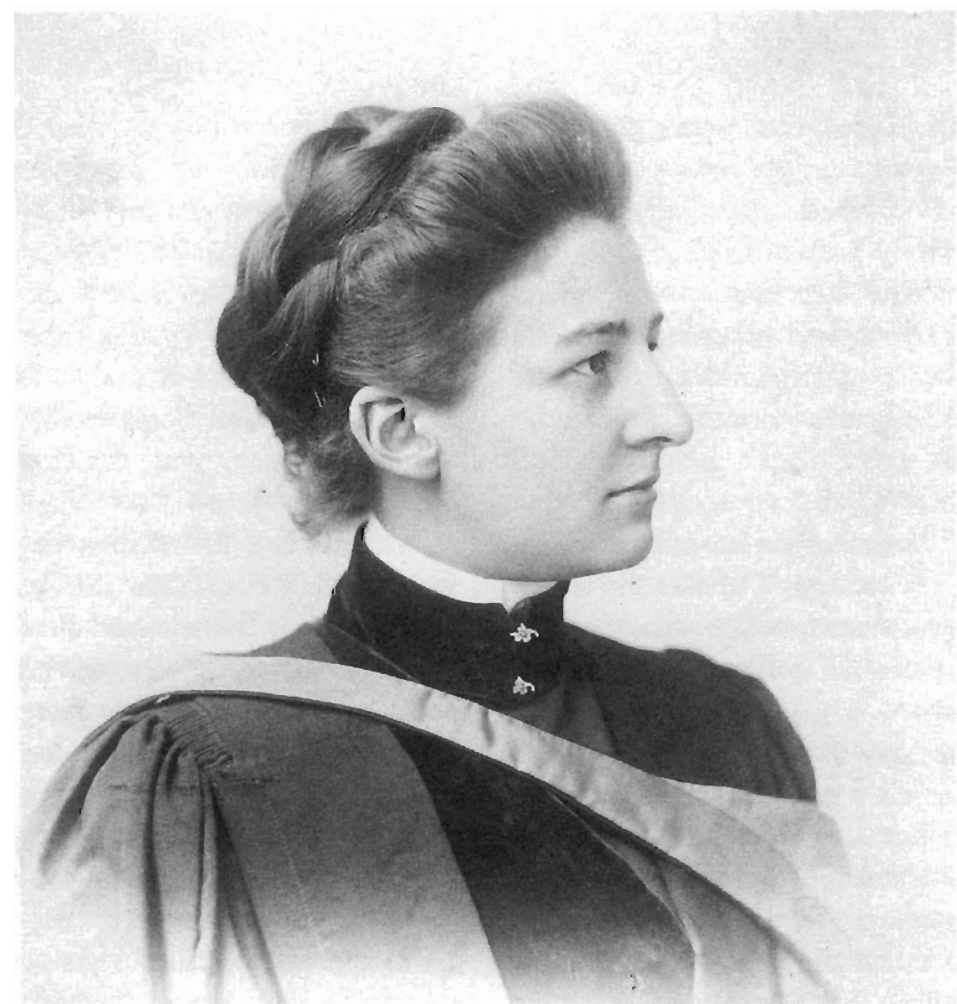

Figure 3. Carrie Derik; first woman full professor in Canada, 1912. (Photo: Notman) 
strategies. For example, after two separate colleges for women were first established at Oxford (Lady Margaret Hall, 1878 and Somerville, 1879), women were allowed to attend University lectures but they were "unofficially present" and did not count as students. Chancellor Lord Curzon who headed an inquiry into university reform, admitted in 1909 that "Oxford yielded to the reality while withholding the name." 5 At Oxford, women gradually won the right to take examinations but were not accorded degrees until 1920. At the University of Toronto, the game was even more astounding. In the early 1880 s, women were allowed to take exams but were not allowed to attend the lectures. Until 1884 when they were officially admitted, they were forced to eavesdrop on the lectures from the corridors. That year, 1884, was also the one in which women were admitted to McGill--but only to the Faculty of Arts and on the basis of separate classes, the accompaniment of a chaperone, and limited library privileges. Women were in but not of the university. This had nothing to do with their abilities, for they proved themselves to be very able scholars; it had everything to do with traditional attitudes.

A constant theme found in the writings of the women students of Phase II was loneliness. Pioneer women, for all their courage and determination, were distressed by innumerable petty humiliations including booby traps placed in their seats, graffiti scrawled on classroom walls, and bawdy stories told by instructors. Elizabeth Smith, one of Canada's first female medical students at Queen's, wrote in 1880, "No one knows or can know what a furnace we are passing through these days at college. We suffer torment, we shrink inwardly, we are hurt cruelly. " She said, "It was so unbearable that on one occasion that one of the ladies went to the lecturer afterwards and asked him to desist from that sort of persecution or she would go and tell his wife exactly what he had said." The male medical students had a much stronger counter-threat. They warned that if the women remained in the Queen's Medical School, they would migrate en masse. The administration succumbed to this threat, so women had to go.

If the female students of Phase $\square$ were uncomfortable, early women instructors did not have an easy time of it either. They were faced with salary differences, few prospects of advancement, no power but much patronizing which was humiliating even when, or especially when, it came from some of the most respected "gentlemen" on campus. For example, Dr. Alice Hamilton, who was an acknowledged expert in industrial diseases, became the first women appointed to the Harvard School of Public Health. So that her appointment would not be considered as a precedent, three ridiculous limitations were placed upon it: Dr. Hamilton was not to participate in the academic procession at convocation; she was not eligible for faculty tickets to the football games; and she was not allowed into the faculty club. Initially, women were not eligible for the McGill Faculty Club, either. In the history of the club, Frank Scott has described "The Great Circle" of discussion around the fire in the lounge enjoyed by men exclusively. ${ }^{7}$ In 1936, when Dr. Maude Abbott (Fig. 4) became the first female member, she was subject to restrictions and for many years the Faculty Club Handbook instructed ladies not to loiter in the entrance but to go quickly upstairs. It informed them that they could not ride in the elevator unless accompanied by a [male] member, that they could not enter the main lounge nor, except for special circumstances, the main dining room.

Women only achieved full membership in the Club after a referendum in 1966. One woman academic who participated in this told me that she voted "No" because she thought it was nice for the men to have a place for themselves. She represented those Phase II women who humbly felt they were intruders in academia and who still revered male authority, no matter what limitations were placed upon them.

\section{PHASE III}

Phase III roughly covers the second half of the 20th century. (You notice the phases are becoming significantly shorter as change accelerates.) One of the most obvious characteristics of Phase $\mathrm{III}$ was the significant increase in the number of female students at universities--the apparent demise of the exceptional few. From the 1970s, women students began to approach half, then more than half of the overall undergraduate population. This was true in North America and many other parts of the world. Currently in Canada, women constitute about $55 \%$ of the undergraduates. This growth has been sustained and, even though it has been unevenly distributed, women can now be found 
Women in the University: The Fourth Phase

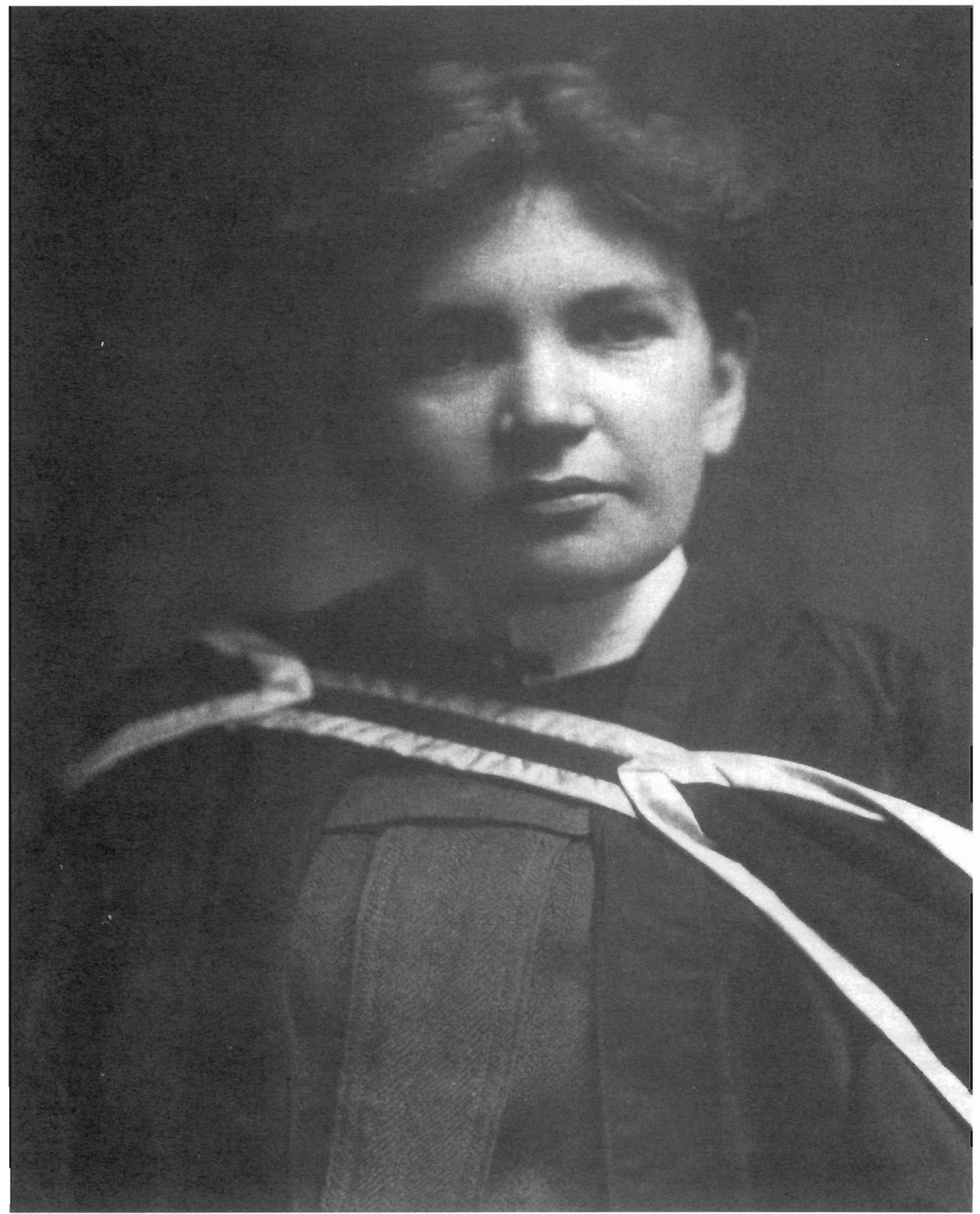

Figure 4. Maud Abbott (1869-1940); first woman member of the McGill Faculty Club. (Photo. Notman) 
studying or teaching in virtually every discipline The numbers of female faculty also rose in Phase III but did not match the proportions of the students. In Canada it hovered between $15 \%$ and $20 \%$ in this period. At present, about $23 \%$ of the tenured faculty at McGill are female, but just under $10 \%$ of the full professors. ${ }^{8}$ This is an improvement over Phase $\Pi$, but does not really constitute a critical mass--a proportion so significant that it must be taken into consideration when all important decisions are being made and can itself affect the decision-making process.

Another Phase III development was that single-sex colleges began to "go co-ed." In the late 1960s, even elite women's colleges such as the "Seven Sisters" in the U.S. and those at Oxford and Cambridge, began to accept male students. There was also a change in the demographic composition of the female population at most institutions. In the previous phase, university women in countries like Canada were usualiy white and middle-class; now there were gradually increasing numbers of women from other social strata and ethnic backgrounds. These developments were obviously reflections of changes in the general intellectual, social, economic and political climates of the second half of our century. Movements such as civil rights, the "second wave" of feminism, human rights and multiculturalism have all made a difference in women's aspirations, opportunities, achievements, and even the way we dress. I recall a minor incident that is symbolic of the early part of Phase III. One wet Saturday in 1964, a woman member of the faculty tried to enter the Macdonald College library wearing slacks discreetly covered by her raincoat. Her dress was deemed inappropriate and she was politely asked to leave. You know it wasn't the raincoat that was objectionable, it was the pants

The problem, perhaps, was that woman was ahead or her time. From about the mid-sixties on, women not only dared to wear pants on campus, in restaurants and other respectable public places, they started to speak out. Great numbers of North American women felt liberated from the isolation of suburban domesticity and male dominance by the ideas in Simone de Beauvoir's La Deuxième Sexe (1952) and Betty Friedan's The Feminine Mystique (1963). In 1967, McGill graduate, Laura Sabia, then president of the Canadian Federation of University Women, threatened Prime Minister Lester
Pearson that, unless be approved a royal commission on the status of women in Canada, she would march on Ottawa with 2,000 women. She was bluffing, but we got the Royal Commission.

In the 70s, McGill students brought in radical feminists like Kate Millett to stir things up on campus (Millett gave her view of it in her book called Flying, 1974) and later Gloria Steinem, on a visit to Concordia, advocated that women abandon the lady-like demeanor of Phase II in favour of "outrageous acts and every-day rebellions."

Especially in the early days of Phase III, there was much talk of "sisterhood." This was clearly manifest in the flourishing of women's conferences. They had a special aura, one tinged with the glamour of forbidden fruit--women talking to women about things that mattered apart from the personal and the familial. Women academics of the era converted time-worn clichés like: "Behind every successful man there is a woman" to "In front of every successful woman there is a man--1n her way" and "Woman's piace is in the home" became "Woman's place is in the home and in the House of Commons."

The strength of the movement can be gauged by the fact that 1975 was declared International Women's Year and 1976-85, International Women's Decade. In 1975 at McGill, we celebrated in several ways, including a special issue of the McGill Journal of Education, ${ }^{9}$ a campus-wide survey of academic interest in research and teaching on women which led to the establishment of the Senate Committee on Women and ultimately to the Centre for Research and Teaching on Women, and a very well supported public lecture series. We were honoured that one of our speakers was Mme Thérèse Casgrain who had done so much to achieve the vote for the women of Quebec in 1940. We celebrated again in 1984 to mark the centenary of women's admission to McGill. One of our forceful speakers that year was Mary Daly, author of Beyond God the Father: Toward a Philosophy of Women's Liberation (1973) and other radical books. She shocked many members of her audience when, instead of congratulating us, she chastised the women of McGill for so humbly and gratefully applauding the fact that we were allowed in. She thought we should have stormed our way through the barriers and rot just waited for men to let us in at their convenience. 
Mary Daly was one of the many determined people of Phase III who helped raise women's awareness of their suppressed status and of their unrealized potential. As a result of their work, there was a proliferation of conscious-raising or "CR" groups, the development of networks, and the articulation of fresh ideas about women's role in academia and their place in the curriculum. Of particular note was the coining of new words such as "sexism" and expressions such as "sexual harassment." Once these phenomena had been named, the Establishment had to acknowledge that they existed, moreover, that they existed in the gentle groves of academe and not just out in the cruel "real world." Universities then appointed administrative officers or units with particular responsibility for the welfare of women students and members of staff. It is true that officials such as Deans of Women existed in Phase UI when the university stood in loco parentis for its students, but in Phase III these positions tended to be based more on notions of social justice than on paternalism or protective motherliness.

Phase III was also a period of open demands for things that could only have been whispered in Phase $I I$ (and not even thought of in Phase I): affirmative action, salary equity, and child care; objections to macho publications like The Plumbers' Pot at McGill and the Lady Godiva rides at U.B.C.; maternity leave, paternity leave, and job sharing arrangements; the appointment of a few women to senior academic positions (again, those exceptional few); and the publication of a seemingly endless stream of reports, papers and books on women, including a history of women at McGill (1981). Phase III was infused with action, excitement, change and achievement. It was a good time to be a woman on campus.

However, as positive as all this was, the patriarchal heritage persisted in many forms including superior male power, inferior status for women and condescending attitudes. The voices of some Phase $\mathrm{II}$ women still echoed the discomforts of Phase II. In the 1980s one young woman reported, much as Virginia Woolf had in the 1920s, that when she walked into an Oxford library she felt that the knowledge contained there did not and could not belong to her. ${ }^{10}$ As for taking a $\mathrm{Ph}$. D. at that ancient foundation, it was almost a subversive act. In 1989, Mary Catherine Bateson, former dean of Faculty at Amherst College, Mass. (and daughter of anthropologist Margaret Mead), wrote about the enduring double standard and "the steady drag of disparagement and prejudice pulling [women] toward the acceptance of subordinate roles." She said, "Nowadays, prejudice is relative, not absolute. There is no fixed rule that excludes, just a different probability....There is always that slight stacking of the deck, the extra stress, the waiting prejudice that amplifies every problem." ${ }^{11}$ Although bias was now more subtle, overt of violent examples of hostility toward women were still evident in occurrences of gang rape on campus and exhibitions like the "No means Yes" banners that "boys just being boys" hung out their dorm windows at Queen's about three years ago. The depths of misogyny were reached in December, 1988, when Marc Lepine at the École Polytechnique murdered 14 students because they were women. Feminists absolutely refused to believe that the massacre was merely the work of an individual psychopath. It was pure misogyny still active in society and academe.

\section{PHASE IV}

We are entering Phase IV right now. Just as the other phases have overlapped each other, so Phase IV is emerging out of Phase III and will probably last well into the next century. You may wonder what it will be like? Since we have seen a progressive movement through Phases II and III, it might be reasonable to suppose that Phase IV might just keep advancing and become a period in which we consolidate our gains. It might be a time when we take gender equity as an uncontroversial given, one that is reflected in all academic policies and practices. Now that enlightened academic leaders are well aware of the harmful and wasteful effects of past prejudices, they might make wholehearted efforts to bring about the just academic society. Recently, Principal Shapiro actively encouraged women to apply for senior positions at McGill and, believe it or not, there is even a hopeful sign in the stark preliminary budget for 1995-96 where Vice-Principal Armour recognises that "provision for pay equity adjustments" is one of the important demands for the future that cannot be neglected. ${ }^{12}$ So it might happen that Phase IV will turn out to be characterized by women's full integration into all aspects of the academic community (Figs. 5-8). 
This is something devoutly to be wished, but there are both present and potential problems. Dangers might be a better word. After all, we live in what seems to be an increasingly violent and constraining world where the media report many discouraging items such as the elimination of the federal Advisory Council on the Status of Women and the alleged demise of the National Action Committee. Even on International Women's Day, 1995, the Montreal Gazette quoted a Canadian woman Senator as saying women are responsible for rearing the men who abuse women. Also on that day, the Toronto Globe and Mail headlined, "Women shunted aside in China" and detailed how, at a news conference for the major forthcoming UN World Conference on Women, eight out of nine people at the head table were men because, they said, "We cannot have women organize this work just because they are women..."!

These current examples of regression could be multiplied endlessly, both at home and abroad, giving the impression that our progress in Phase III may have been only a thin veneer. Paula Caplan's recent Lifting a Ton of Feathers (1993), showed that despite 110 formal inquiries about the status of women in Canadian universities in the last three decades, patriarchal attitudes have not changed much. The academic context is still infused with a residual belief in male superiority and, even if we achieve what is considered to be a critical mass of women, we have to remember that numbers are not as important as ideology. This is not just a problem for women in universities, as another recent book shows. Sydney Sharpe's The Gilded Ghetto: Women and Political Power in Canada (1994) concluded that, despite the record number of 53 women $(18 \%)$ in our present parliament of 295 , female politicians still "do not rate." They are still routinely mistaken by attendants for secretaries, wives or visitors, considered fair game for sexist remarks by other MPs, and criticized by the press if they indulge in the rowdy badinage that passes muster for debate among the men. Sharpe's picture shows that we still have a "relentlessly male institution" on the Hill, as Caplan's does for academia.

On the other hand, we no longer have the advantage of having a clearly discernable common enemy so we may, paradoxically, become complacent and even victims of our own success. While we are very glad to have Women's Studies classes, which in Phase III were joys to teach, we now find them increasingly difficult and are distressed when some students try, in the name of female solidarity, to impose "guilt trips" on female professors if they give low grades. ${ }^{13}$ Phase IV may actually be a more dangerous time for women as we adjust more comfortably to the male norms and the male establishment becomes more accepting of women. Some women now have become "honorary males."

To become an "honorary male" was a response for some newcomers of Phase II and a strategy of others in Phase III, especially those who wanted to be known as scholars and did not want to be categorized as "women" or "women-professors" or other hyphenated terms. Some of these--perhaps another "exceptional few"-seem to have been immune from any sense of exclusion or loneliness. Whether it is a question of their particular personalities, or their good fortune to have had strong mentors and especially sympathetic colleagues, they have been able to ignore what has been identified as "the chilly climate"14 for women in academe. Some of them contemptuously reject the idea of affirmative action because they see it as both an unnecessary and demeaning form of special pleading. About two years ago the McGill Association of University Teachers was considering a moderate resolution to recommend the making of 25 merit-based appointments of women in an attempt to achieve gradually parity of numbers of male and female professors at McGill. It produced a long and stormy meeting in which two of the most strenuous objectors were a young woman in a male-stereotyped discipline and a senior woman in a humanities area. The senior woman, who seemed completely to misunderstand the ideal of equity, stridently objected to what she called "the cuntification" of the university. Her extraordinary word startled everyone, and whether it was that word or not I don't know, but the resolution was finally turned down. No recommendation about gender equity went forward then and parity remains a long way off.

In Phase IV, however, women will have at least two other options besides becoming honorary males. One is, again paradoxically, to acknowledge that women, their opinions, and their research interests tend to be marginalized and to accept this marginalization as an inherent part of a valuable but flawed institution. Some women now voluntarily withdraw from the struggle and 
Women in the University: The Fourth Phase

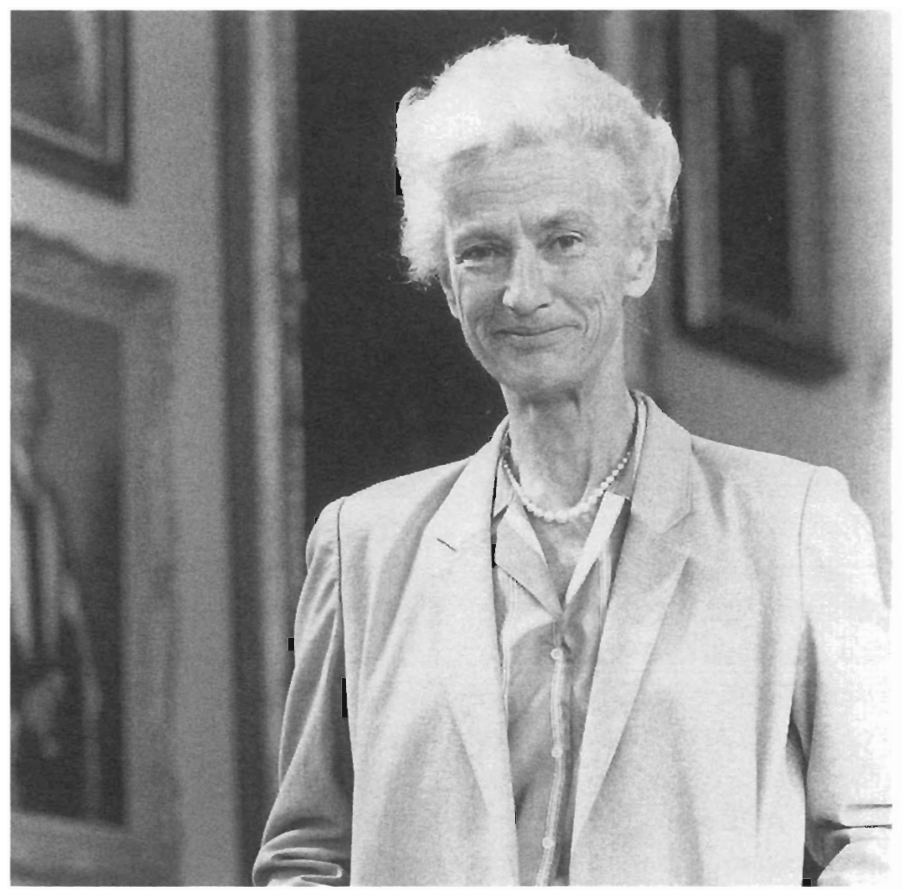

Figure 5. Greta Chambers; first woman Chancellor, 1992. (Photo: Norman Blouin)

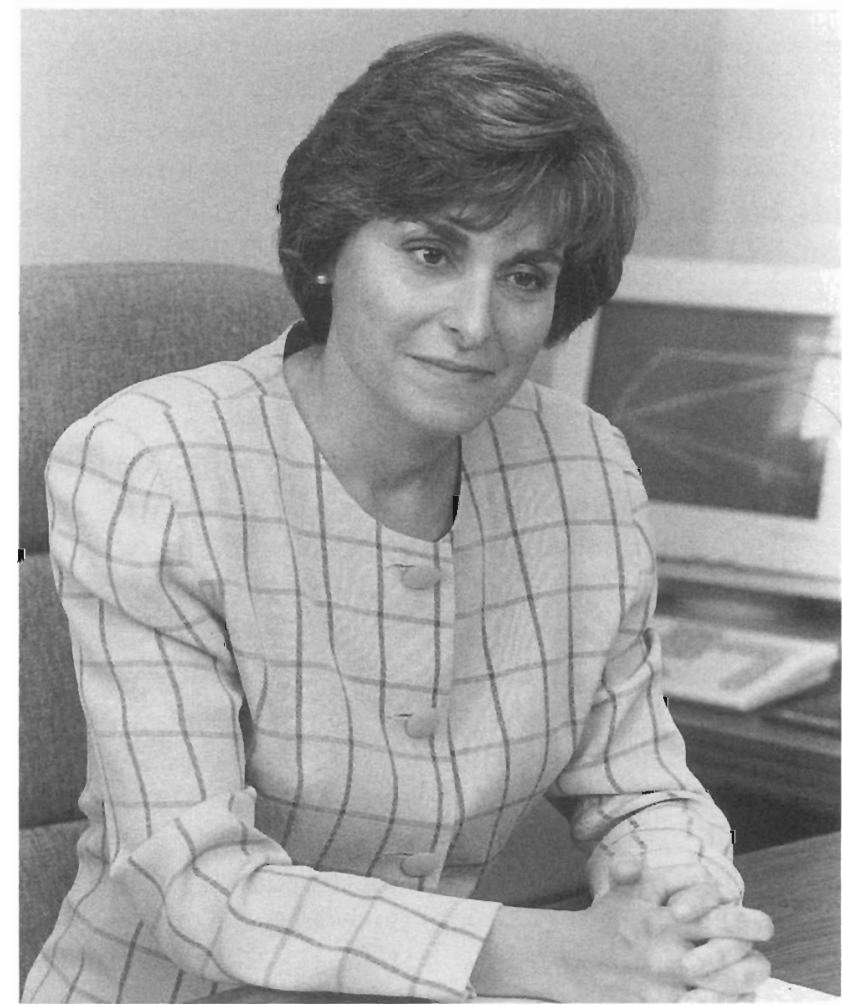

Figure 6. Phyllis Heaphy; first woman Vice-Principal, 1995. (Photo: Jonas Papuretis) 
Women in the University: The Fourth Phase

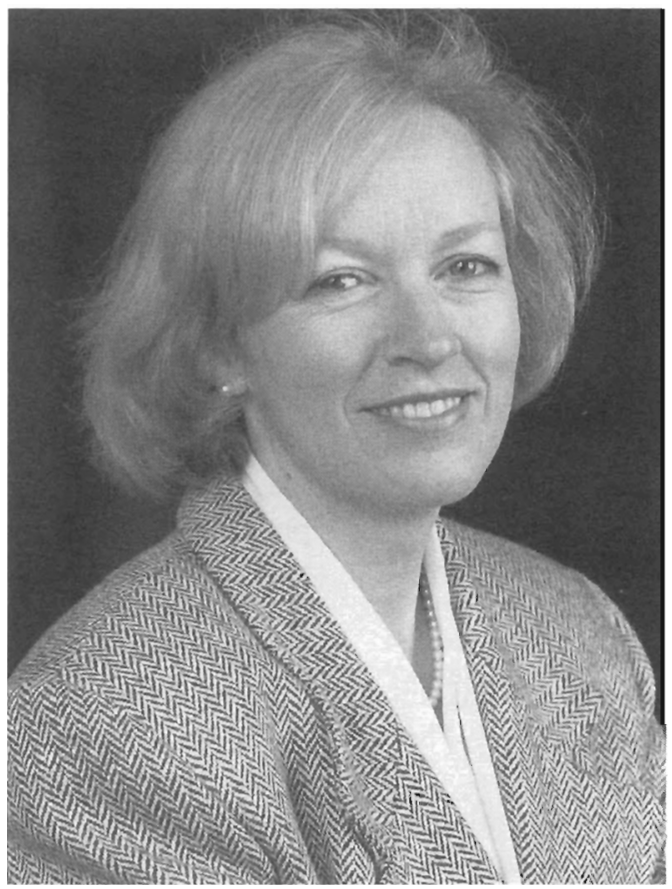

Figure 7. Victoria Lees; first woman Secretary-General, 1995. (Photo: Owen Egan)

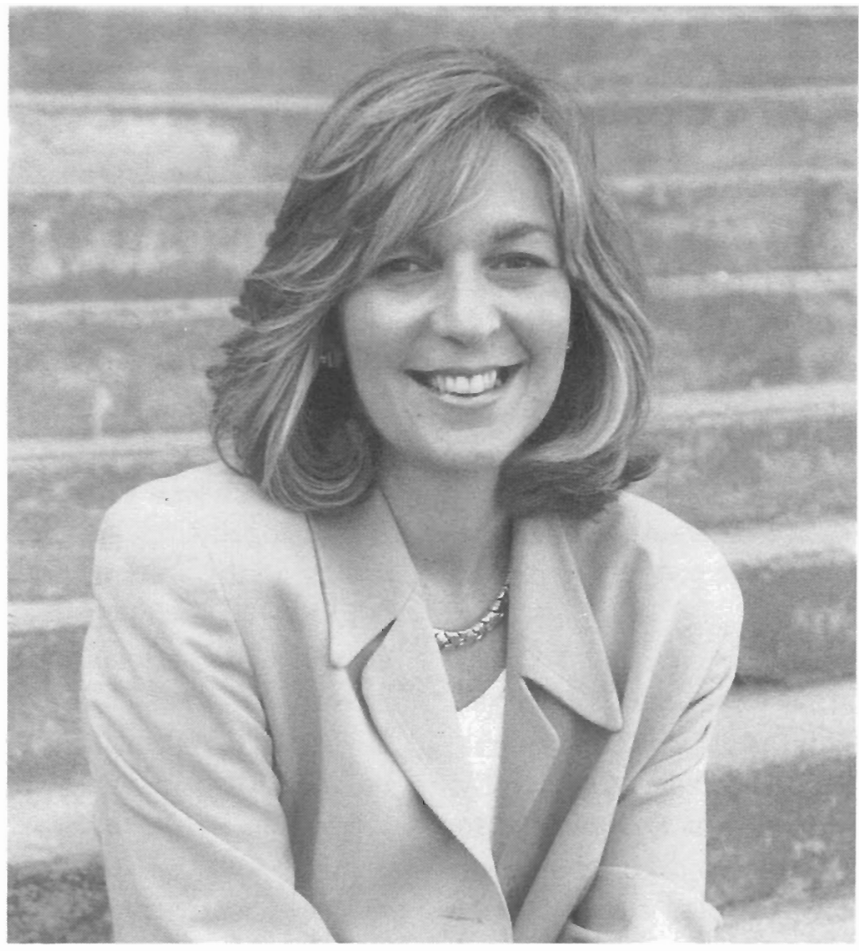

Figure 8. Rosalie Jukier, first woman Dean of Students, 1995. (Photo: Owen Egan) 
go about their own scholarly affairs. Dr. Ruth Hubbard, a Professor of Biology at Harvard and the first Muriel V. Roscoe Lecturer at McGill (1989), chose this "disidentifying" path. In her book, The Shape of Red (1989), she wrote that she actually found strength in the feeling that she was an outsider. Surprisingly, this is an option that Virginia Woolf may have supported. She said in Three Guineas (1938) that women must have enough education and power to be able to remain outsiders in order to retain their identities. However, as Ruth Hubbard recognized, there is a serious disadvantage with this option. She said, "I have jeopardized my effectiveness in departmental politics and virtually eliminated myself from the decision-making process. ${ }^{15}$

Apart from becoming "honorary males" or remaining outsiders, there is another choice for women in Phase IV. This third option is to recognize that, over time, we have positively changed the nature of the university and can continue to do so. We have successfully managed to make changes to the curriculum, to get some long-neglected women rewritten into our disciplines; we have challenged the notion that scientific research is necessarily objective, showing that gender bias has lain hidden in the questions asked, the interpretations made, and the funds available; we have chipped away at male complacency and shown that we can do teaching, conduct research and contribute to the academic community. Many would agree with the McGill woman who wrote recently:

Women reflect and react differently from men in certain situations--not necessarily more wisely, but differently...[and] it makes many of us impatient when men pretend that their way of thinking is inclusive. ${ }^{16}$

Women who choose the third option want to retain the difference, want it accepted and respected. They do not want to be made over.

Yet, even if they do not want to become "old boys" they would like the privileges accorded to the members of "the old boys' network." They want to be fully admitted to the scholarly community as a whole and to have this acknowledged; to be given major responsibilities; to have, for example, an all-female $\mathrm{Ph} . \mathrm{D}$. committee as respected as an all-male one; and to have research on women be taken seriously. Yet, under the pressures of the new entrepreneurial university with larger classes, fewer professors, and less security, some of the very things that women have held most dear will be threatened. These are things that not only permitted the development of individual scholars, but also held promise of humanizing academia--personal qualities like caring in our dealings with students, qualitative methodologies in the quest for truth, co-operation rather than competition in dealings with colleagues. No one would ever wish to restore the biases and restrictions of Phase II just for the sake of preserving "difference." However, it must be recognized that differences may not only be endangered by overt discrimination, they may be obliterated by stress, fatigue and economic expediency.

As we make our way through the "Nasty Nineties," the third option for women seems to offer most. But women are still vulnerable and we must see to it that institutions do not put their relatively few women on endless, exhausting committees as tokens to "political correctness." At McGill we must be concerned about other women as well as ourselves and inquire into how much a hostile cultural climate contributed to the tragic death last year of Dr. Justine Sergent and her husband; and we must watch closely the effects of the recent collapsing of the position of Equity Officer into the double job of Assistant to the Principal and Equity Officer.

Phase IV is not going to be easy. That much is obvious. But it will also have marvellous potential that university women must realize. It will truly be the Information Age, in which the current conveniences of the internet, CD-Roms and all the advances of science and technology will expand exponentially. Digital concordance will bring all scholars of the world much closer together. Women can end their isolation by joining in the work to be done on campus as well as by joining e-mail groups. These range from the new, very general International Women's Policy, Action and Research List, established by the Advisory Council on the Status of Women, to very specialized networks like the Jane Austen E-mail Group, which was begun by Dr. Jacqueline Reid-Walsh of McGill. It would be a big mistake to think that women will automatically be accorded a fair share of the future. We have to stake our claim for it actively. 
While we learn from the past, appreciate the accomplishments of our foremothers and all those who helped us, I hope we will take up the challenge issued to academic women by Caroline Heilbrun when she said:

I do not believe death should be allowed to find us seated comfortably in our tenured positions... Instead, we should make use of our security, our seniority, to take risks, to make noise, to be courageous, to become unpopular. ${ }^{17}$

I think this is the kind of advice of which Frank Scott would have approved and before I step off the stage, I should like to remind you of his poem, "On Saying Goodbye to my Room in Chancellor Day Hall" which begins: "Rude and rough men are invading my sanctuary." As Frank Scott packed to leave McGill, he contemplated the books, files, memorabilia that "cry out [his] history, " he said:

These are all cells to my brain, a part of my total. Each filament thought feeds them into the process By which we pursue the absolute truth that eludes us. ${ }^{18}$

As I leave you to rejoin your own quests for the elusive truth, I remind you of Scott's opening line:

Rude and rough men are invading my sanctuary. And I say to the women of McGill, "Don't let them!"

\section{Notes}

1. Christine de Pizan, The Treasure of the City of Ladies (Harmondsworth, Middlesex: Penguin, 1985).

2. Margaret Gillett, We Walked Very Warily: A History of Women at McGill (Montreal: Eden Press, 1981), 33-4.

3. Ital., 70.

4. Margaret Gillett, "Carrie Derick and the Chair of Botany at McGill," in Marianne G. Ainley, ed., Despite the Odds: Essays on Canadian Women and Science (Montreal: Vehicule Press, 1990), 74-83.

5. Lord Curzon of Kedleston, Principles and Methods of University Reform (Oxford, Clarendon, 1909).

6. Elizabeth Shortt Smith, Historical Sketch of Medical Education, Kingston, Canada (Ottawa, Private Printing, 1916), 1.
7. Carman Miller, ed. A History of the McGill Faculty Club (Montreal: The Club, 1975).

8. Honora Shaughnessy, Director, Annual Report, 1993/94 (Montreal, McGill University Employment Equity Office), passim.

9. McGill Journal of Education, Spring, 1975.

10. Ann Beer, "On Being Lucky," in Margaret Gillett and Ann Beer, eds., Our Own Agendas: Autobiographical Essays by Women Associated With McGill University

(Montreal: McGill-Queen's University Press, 1995).

11. Mary Catherine Bateson, Composing a Life (New York: Plume, 1990), 37.

12. "1995-96 Preliminary Budget," The McGill Reporter, February 23, 1995, 10.

13. For example, Lynn Pearce, "Gender and the Classroom Climate: Overstepping the Boundaries. Student Demands on Female Staff" (Montreal: McGill Centre for Research and Teaching on Women: Unpublished paper, 1995).

14. "Chilly climate" was probably first used by the American Association for University Women to describe unfriendly attitudes and limited opportunities form women on campus. It has been used frequently in Canada, for example, in 1992 a "Climate Committee" was set up at the University of Victoria "in response to the concerns raised...regarding the discouraging and unsupportive environment experienced by graduate and undergraduate women students" in the Department of Political Science (Report of the Climate Committee, March 23, 1993, p. 1); and in June 1993 the Canadian Association for Women's Studies struck a subcommittee to investigate how "chilly climate" reports have been received on campuses across Canada.

15. Ruth Hubbard, The Shape of Red: Insider/Outsider Reflections (San Francisco: Cleis Press, 1989).

16. Kate Williams, "Split Infinitives" in Gillett and Beer, op. cit.

17. Carolyn G. Heilbrun, Writing a Woman's Life (New York: Ballantine, 1988), 131.

18. F.R. Scott, "On Saying Goodbye to my Room in Chancellor Day Hall" in The Collected Poems of F.R. Scott (Toronto: McClelland and Stewart, 1981), 218-9. 